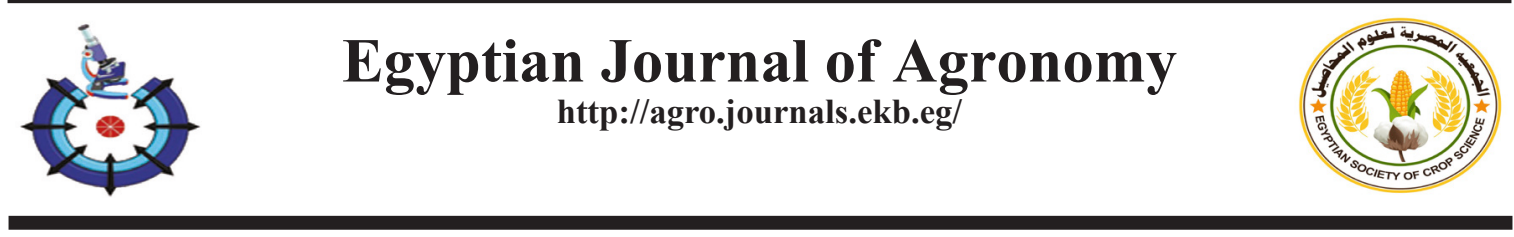

\title{
Using Vinasse as a Source of Potassium Fertilization for Sugar Beet and a Sandy Soil Amendment
}

\author{
Soha R.A. Khalil ${ }^{(1)}$, B.S.I. Makhlouf ${ }^{(2) \#}$, Khadiga I.M. El-Gabry ${ }^{(3)}$ \\ (1)Sugar Technology, Research Department, Sugar Crops Research Institute, \\ Agricultural Research Center (ARC), Giza, Egypt; (2) Agronomy Research Department, \\ Sugar Crops Research Instituet, Agricultural Research Center (ARC), Giza, Egypt; \\ ${ }^{(3)}$ Microbiology Research Deptartment, Soils, Water and Environment Research \\ Institute, Agricultural Research Center (ARC), Giza, Egypt.
}

$\mathbf{T}$ WO field experiments were conducted in a sandy soil at Al-Hossein Agricultural Farm located at $64^{\text {th }} \mathrm{km}$, Cairo-Alexandria Desert Road, Egypt, in 2017/2018 and 2018/2019 seasons, to check the possibility of using cane vinasse as a source of potassium fertilization for sugar beet, and its effect as an amendment on some properties of soil. A randomized complete block design was used. The present work included 13 treatments as follows:

- $100 \% \mathrm{~K}_{2} \mathrm{O}: 48 \mathrm{~kg} \mathrm{~K}_{2} \mathrm{O} / \mathrm{fed} \mathrm{"fed}=4200 \mathrm{~m}^{2}$ " as $\mathrm{K}_{2} \mathrm{SO}_{4}$ " $48 \% \mathrm{~K}_{2} \mathrm{O}$ " (control).

- Three treatments represent the sole application of $100 \%$ equivalent to $48 \mathrm{~kg} \mathrm{~K}_{2} \mathrm{O} / \mathrm{fed}$, in the form of raw $\left(\mathrm{V}_{1}\right)$, photo-chemically $\left(\mathrm{V}_{2}\right)$ and biologically $\left(\mathrm{V}_{3}\right)$ treated vinasse, i.e., 707.6, 707.6 and $817.7 \mathrm{~L} / \mathrm{fed}$, respectively.

- Nine treatments, using 75, 50 and $25 \%$ of the recommended rate as $\mathrm{K}_{2} \mathrm{SO}_{4}$ combined with 25,50 and $75 \%$, successively, equivalent to $48 \mathrm{~kg} \mathrm{~K}_{2} \mathrm{O} /$ fed, from each of $\mathrm{V}_{1}, \mathrm{~V}_{2}$ and $\mathrm{V}_{3}$.

The lowest value of hydroxyl methyl furfural (HMF) was recorded with $\mathrm{V}_{3}$ and phenolic compounds with $\mathrm{V}_{2}$. The maximum activity of dehydrogenase enzyme was found with adding $\left(50 \% \mathrm{~K}_{2} \mathrm{O}+50 \% \mathrm{~V}_{3}\right) /$ fed. Adding $\left(50 \% \mathrm{~K}_{2} \mathrm{O}+50 \% \mathrm{~V}_{3}\right)$ significantly increased root yield/fed. The different treatments including $\mathrm{V}_{3}$ markedly increased sugar yield/fed, as compared to that gained with $100 \% \mathrm{~K}_{2} \mathrm{O} / \mathrm{fed}$, in both seasons.

The addition of $\left[50 \%\right.$ of the recommended rate of $\mathrm{K}$-fertilizer $\left(24 \mathrm{~kg} \mathrm{~K}_{2} \mathrm{O}\right)$ as $\mathrm{K}_{2} \mathrm{SO}_{4}+50 \%$ of the biologically treated vinasse ( 408.85 liters)/fed] could be recommended to get economical root and sugar yields, which means saving $50 \%$ of mineral potassium sulphate required for sugar beet crop.

Keywords: Fertilization, Potassium, Sandy soil, Sugar beet, Vinasse treatments.

\section{Introduction}

In the last decade, the application of industrial by-products to soil has been performed to reclaim degraded soils, supply plant nutrients at a lower cost, and preserve the organic matter levels in soil (Tejada et al., 2008). Beet and sugarcane vinasse are the final by-product of the cycle of distillation of alcoholic liquor, yeast and amino/organic acid fermentation of sugarcane and/or beet molasses, a by-product of the sugar processing. Often known as distillery stillage or slopes is diluted vinasse, which has the highest organic content and high conductivity an BOD. Diluted vinasse is used widely as organic fertilizer (Parnaudeau et al., 2008). Vinasse was documented as an agricultural fertilizer for recycling NPK and water in organic crop production since 1940 (Fuess et al., 2017). In this concern, Parnaudeau et al. (2006) indicated that vinasse contains

"Corresponding author email: basemssee@gmail.com

Received 27/7/ 2020; Accepted 19/10/ 2020

DOI: 10.21608/agro.2020.37407.1222

C2020 National Information and Documentation Center (NIDOC) 
important macro minerals such as $\mathrm{N}, \mathrm{K}, \mathrm{Ca}$ sulfate and $\mathrm{Mg}$, vitamins and organic acids such as vitamin B complex and amino acids from yeast autolysis, which are required for crop production and soil organic matter content improvement. Therefore, it is used as a soil-conditioner to produce beneficial microorganism in the soil. It also contains chelated organic material which contains micronutrients such as Fe, $\mathrm{Mn}, \mathrm{Zn}$, and $\mathrm{Cu}$. In addition, vinasse contains some organic acids such as acetic, lactic, nicotinic, malice, and citric acids which can play an important role in reducing soil alkalinity. Meanwhile, the fulvic acids included in the vinasse have a molecular average weight of 4500 gallic acid $/ \mathrm{mol}$, which enables them to generate coordinated bonds with bivalent and trivalent cations, producing complex chelates of iron, copper, manganese, zinc and boron (Decloux \& Bories, 2002; Christofoletti et al., 2013). On the other hand, melanoidins, owing to the Maillard reaction, result in the reaction of sugars and proteins, caramel and furfural components contribute to their color and make vinasse a complex and difficult wastewater for degradation. (España et al., 2011). Vinasse have a higher concentration of furanic compounds \{furfural and 5-(hydroxymethyl) furfural which considered one of potential inhibitors for dark fermentative (Rodríguez-Félix et al., 2018). In addition, the small molecular mass of compounds contained in vinasses can include melanoidins and phenolic compounds that can inhibit or decrease activity of micro-organism (Fitz-Gibbon et al., 1998). Consequently, vinasse is considered a high material in chemical oxygen demand (COD) and biochemical oxygen demand (BOD) levels have been reported to range from 50 to $150 \mathrm{~kg} / \mathrm{m}^{3}$ and from 20 to $80 \mathrm{~kg} / \mathrm{m}^{3}$, respectively (España et al., 2011). So, there are several methods such as dewatering by physiochemical processes to drier effluents or using it with smaller amounts by dilution or treating it with ozone to manage the use of vinasse in agriculture by optimal un-harmful ways (Chen et al., 2012; Nkoa, 2014), which lead to a decrease of about $95 \%$ of the COD, complete disposal of phenolic compounds, and over $80 \%$ of total-nitrogen (Júnior et al., 2016; Reis et al., 2019).

Concerning the usage of vinasse as an organic nutritional source and a soil amendment, González \& Mejia (2015) determined the effect of fertigation with vinasse over 50 years on the quality of groundwater. They found that the aquifer has the potential to be contaminated by deep percolation of irrigation water. Therefore, a conditioning treatment must be applied to this wastewater before it is disposed of in the environment. They added that, using vinasse for some crops was successful.

Potassium is an important element for multiple roles in plant growth, enhancing the photosynthetic process, maintaining cell turgidity and regulating the water content of plant tissues as well as it is essential for the activation of some enzymes within cells (Hasanuzzaman etal., 2018). Moreover, potassium has a specific function in sugar translocation from source (leaves) to the sink (storage roots). Therefore, many researches had studied vinasse dosage which could be substituting the fertilizer requirements for many crops, e.g., Arafat \& Yassen (2002) cleared that about $62 \%$ of $\mathrm{P}$ and $100 \%$ of $\mathrm{K}$ required for wheat yield. Also, Rodríguez (2000) mentioned that, adding $50 \mathrm{~m}^{3}$ vinasse $/ \mathrm{ha}^{-1}$ would substitute $55 \%$ of $\mathrm{N}, 72 \%$ of $\mathrm{P}_{2} \mathrm{O}_{5}$ and $100 \%$ of $\mathrm{K}_{2} \mathrm{O}$ that has to be applied using mineral fertilization to produce a great sugar and cane yields. AbdEl-Kaway (2006) showed that, the addition of vinasse and potassium sulphate caused a slight decrease in $\mathrm{pH}$ and a slight increase in salinity EC of the soil. Vinasse has been mostly used on practices of fertigation, reducing the water input for plant growth (Walter et al., 2011). Fertigation usually has negative effects on the soil and groundwater in the long term (Rocha et al., 2007). Vadivel et al. (2014) concluded that, using vinasse in agriculture added a substantial amount of nutrients, improved the quality of degraded soil, as well as increased crop yields. In this regard, Osman et al. (2016) indicated that the use of diluted vinasse $(20 \%)$ with $25 \%$ of the mineral potassium fertilizer required for sandy soil has added substantial amount nutrients, especially $\mathrm{K}$ and organic matter, which improved soil chemical properties, nutritional status and crop yield. Ferweez \& Abd El-Monem (2018) concluded that the application of $24 \mathrm{~kg} \mathrm{~K}_{2} \mathrm{O} /$ fed achieved the maximum values of recoverable sugar yield, sugar recovery, quality index and sucrose percentages, while it contained the lowest values of sugar lost to molasses\%, a-amino $\mathrm{N}$ and $\mathrm{Na}$ contents.

This trial was carried out to evaluate the use of different forms of chemically and biologically 
treated cane vinasse as a substitute, in variable proportions of mineral potassium fertilizer and to study its effects on yield and quality of sugar beet, as well as an amendment on some properties of sandy soil.

\section{Materials and Methods}

Two field experiments were conducted in a sandy soil at Al-Hossein Agricultural Society Farm located at $64^{\text {th }} \mathrm{km}$, Cairo-Alexandria Desert Road, Giza Governorate, Egypt, (latitude of $31.14^{\circ} \mathrm{N}$ and longitude of $31.39^{\circ} \mathrm{E}$ ) in $2017 / 2018$ and $2018 / 2019$ seasons to investigate the possibility of using cane vinasse as a source of potassium fertilization for sugar beet, as well as its effects as an amendment on some properties of sandy soil. Sugar beet variety viz "Hamza" was sown under drip irrigation system conditions in both seasons. The present work included 13 treatments as follows:

- $100 \% \mathrm{~K}_{2} \mathrm{O}$ (control): $48 \mathrm{~kg} \mathrm{~K}_{2} \mathrm{O} /$ fed (the recommended rate of potassium fertilizer) as potassium sulphate " $48 \% \mathrm{~K}_{2} \mathrm{O}$ ".

- Three treatments represent the sole application of $100 \%$ equivalent to $48 \mathrm{~kg} \mathrm{~K}_{2} \mathrm{O} / \mathrm{fed}$, in the form of raw $\left(\mathrm{V}_{1}\right)$, photo-chemically $\left(\mathrm{V}_{2}\right)$ and biologically $\left(\mathrm{V}_{3}\right)$ treated vinasse, i.e., 707.6, 707.6 and 817.7 1/fed, respectively.

- Nine treatments, using 75, 50 and 25\% of the recommended rate as potassium sulphate combined with 25,50 and $75 \%$, successively, equivalent to $48 \mathrm{~kg} \mathrm{~K}_{2} \mathrm{O} /$ fed from each of $\mathrm{V}_{1}$, $\mathrm{V}_{2}$ and $\mathrm{V}_{3}$.

Raw vinasse used in the study came from a first generation ethanol plant (ethanol from fermentation) of sugar cane juice. Raw vinasse was brought from Egyptian Sugar \& Integrated Industries Co., El-Hawamdia, Giza, Egypt.

Some physical properties of soil of the experimental site were analyzed using the procedure described by Black et al. (1981). Soil chemical analysis was determined according to the method of Jackson (1973). Some physical and chemical analyses of the experimental soil (at $50 \mathrm{~cm}$ depth) are presented in Table 1.

Chemical and biological treatments of vinasse

To get maximum degradable phenolic compounds and hydroxyl methyl furfural (HMF) in vinasse, some photochemical and biological treatments were carried out according to the methods described by Afify et al. (2009) as follows:

A. Photo-chemical treatment: This treatment was performed on vinasse solution, the optimum conditions of phenolic compounds decomposition were done by oxidation using $\mathrm{H}_{2} \mathrm{O}_{2}$ solutions $(30 \% \mathrm{w} / \mathrm{v})$ at $0.55 \mathrm{M}$ at a $\mathrm{pH}$ of 5 , then the solution was subjected to UV radiation using an UV lamp (Camag Co. Ltd., Switzerland) at $254 \mathrm{~nm}$ for $150 \mathrm{~min}$. (The energy consumed by UV lamp/150min= $3.1289 \times 10^{-18}$ watt).

B. Biological treatment: The fungus Pleurotus ostreatus was provided from Microbiology Res. Dept., Soil, Water and Environ. Res. Inst., Agric. Res. Center, Egypt. Potato Dextrose Agar (PDA) medium was used for maintenance of the fungus. The microbial strain was sub-cultured every 30 days and maintained at $4^{\circ} \mathrm{C}$. The fungus was grown mainly in $250 \mathrm{~mL}$ conical flask containing $50 \mathrm{~mL}$ of sterilized $5 \%$ vinasse $\left(121^{\circ} \mathrm{C}\right.$ for $20 \mathrm{~min})$. The flasks were incubated at $25^{\circ} \mathrm{C}$ on a rotary shaker (150rpm) for one week. Then each flask was used to inoculate for 6 litres container containing 3 liters of sterilized $20 \%$ vinasse sealing up. The congeners were incubated at $25^{\circ} \mathrm{C}$ in good aeration for two weeks and then used for further bioexperiments.

The following data were recorded in vinasse samples

Electrical conductivity (EC), organic matter\% (OM), $\mathrm{pH}$, total nitrogen, potassium $(\mathrm{K})$ and phosphorus (P) were determined as described in A.O.A.C. (1980). Total phenols were estimated using Spectrophotometer according to Swain \& Hillis (1959). HMF was determined as mentioned by Zappalaa et al. (2005). Chemical oxygen demand (COD) and biological oxygen demand (BOD) were determined according to the method described by APHA (1992), and color concentration was monitored using Spectrophotometer at $455 \mathrm{~nm}$. according to Benito et al. (1997). Some physical and chemical properties of raw vinasse are presented in Table 2. 
TABLE 1. Some physical and chemical analyses of the experimental soil (at $50 \mathrm{~cm}$ depth)

\begin{tabular}{|c|c|c|c|c|c|c|c|c|c|c|c|}
\hline \multirow{2}{*}{ Seasons } & \multicolumn{6}{|c|}{ Particle size distribution } & \multirow{2}{*}{\multicolumn{2}{|c|}{ Soil texture }} & \multirow{2}{*}{$\begin{array}{c}E C \\
(d S / m)\end{array}$} & \multirow{2}{*}{\multicolumn{2}{|c|}{$\begin{array}{c}\text { pH } \\
(1: 2.5)\end{array}$}} \\
\hline & \multicolumn{2}{|c|}{ Sand $\%$} & \multicolumn{2}{|c|}{ Silt $\%$} & \multicolumn{2}{|c|}{ Clay \% } & & & & & \\
\hline $2017 / 18$ & \multicolumn{2}{|c|}{91.3} & \multicolumn{2}{|c|}{4.9} & \multicolumn{2}{|c|}{3.8} & \multicolumn{2}{|c|}{ Sandy } & 0.59 & \multicolumn{2}{|c|}{7.9} \\
\hline $2018 / 19$ & \multicolumn{2}{|c|}{91.7} & \multicolumn{2}{|c|}{4.3} & \multicolumn{2}{|c|}{4.0} & \multicolumn{2}{|c|}{ Sandy } & 0.72 & \multicolumn{2}{|c|}{8.1} \\
\hline \multirow{2}{*}{ Seasons } & \multicolumn{4}{|c|}{ Soluble cations (meq $\left.L^{-1}\right)$} & \multicolumn{3}{|c|}{ Soluble anions (meq $\left.L^{-1}\right)$} & \multirow{2}{*}{$\mathrm{CaCO}_{3 \%}$} & \multicolumn{3}{|c|}{$\begin{array}{l}\text { Available nutrients } \\
\text { (mg/1 kg soil }))\end{array}$} \\
\hline & $\mathbf{C a}^{++}$ & $\mathbf{M g}^{++}$ & $\mathbf{N a}^{+}$ & $\mathbf{K}^{+}$ & $\mathrm{HCO}_{3}^{-}$ & $\mathrm{SO}_{4}^{--}$ & $\mathrm{Cl}^{-}$ & & $\mathbf{N}$ & $\mathbf{P}$ & $\mathbf{K}$ \\
\hline $2017 / 18$ & 2.4 & 0.7 & 2.58 & 0.22 & 0.53 & 2.47 & 2.9 & 0.56 & 26 & 1.8 & 82 \\
\hline $2018 / 19$ & 3.2 & 0.4 & 3.30 & 0.28 & 0.56 & 3.32 & 3.3 & 0.49 & 32 & 2.0 & 96 \\
\hline
\end{tabular}

TABLE 2. Some physical and chemical characteristics of raw vinasse $\left(V_{1}\right)$

\begin{tabular}{|c|c|c|c|c|c|c|c|c|c|c|c|c|}
\hline \multirow{2}{*}{$\begin{array}{l}\text { Moisture } \\
\%\end{array}$} & \multirow[t]{2}{*}{ Density } & \multirow{2}{*}{$\begin{array}{l}\text { Color } \\
\text { conc. }\end{array}$} & \multirow[t]{2}{*}{ pH } & \multirow{2}{*}{$\begin{array}{c}\text { EC } \\
(\mathrm{dS} / \mathrm{m})\end{array}$} & \multirow[t]{2}{*}{$\begin{array}{c}\text { OM } \\
\%\end{array}$} & \multirow{2}{*}{$\begin{array}{c}\text { HMF } \\
\text { (ml/100ml) }\end{array}$} & \multirow{2}{*}{$\begin{array}{c}\text { Total } \\
\text { phenols } \\
\text { (ppm) }\end{array}$} & $\mathbf{K}$ & $\mathbf{P}$ & $\mathbf{T N}$ & COD & BOD \\
\hline & & & & & & & & \multicolumn{3}{|c|}{$\%$} & \multicolumn{2}{|c|}{$\mathrm{mg} \mathrm{O} / \mathrm{L}$} \\
\hline
\end{tabular}

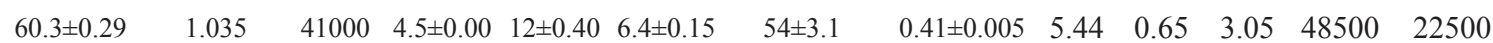

OM: Organic matter, HMF: Hydroxyl methyl furfural, TN: Total nitrogen, COD: Chemical oxygen demand and BOD: Biological oxygen demand.

A randomized complete block design with three replications was used. Plot area was $24 \mathrm{~m}^{2}$ including 4 ridges of $60 \mathrm{~cm}$ in width and $10 \mathrm{~m}$ in length with $20 \mathrm{~cm}$ between hills. Overall dose of $30 \mathrm{~kg} \mathrm{P}_{2} \mathrm{O}_{5} /$ fed was added in the form of calcium super-phosphate $\left(15 \% \mathrm{P}_{2} \mathrm{O}_{5}\right)$ during seedbed preparation. Nitrogen fertilizer was applied at $100 \mathrm{~kg} \mathrm{~N} / \mathrm{fed}$ as ammonium nitrate " $33.5 \% \mathrm{~N}$ " in 4-equal dose; the $1^{\text {st }}$ dose was added after thinning (4-6 true-leaf stage) and the other three ones were applied at two-week interval after the first application. Potassium sulphate, vinasse and their combinations were applied as fertigation in 3 -equal dose, the $1^{\text {st }}$ one was applied with the $2^{\text {nd }}$ $\mathrm{N}$-dose and the two other ones were added at the same time of applying nitrogen doses. Sugar beet variety was sown in the $1^{\text {st }}$ week of November in the $1^{\text {st }}$ season and the $4^{\text {th }}$ week of October in the $2^{\text {nd }}$ one, while harvesting was done at age of 210 days, in both seasons. The preceding crop was sorghum. Other field practices were done as recommended by Sugar Crops Research Institute.

The following data were recorded for the experimental soil after 40 days from the last application of treatments

Electrical conductivity, $\mathrm{pH}, \mathrm{K}$ and $\mathrm{P}$, total nitrogen and organic carbon $\%$ were determined as described in A.O.A.C. (1980). Dehydrogenase enzyme activity $(\mu \mathrm{g}$ of triphenyl formazan/g dry soil/day) was determined according to Thalmann (1967).

\section{Sugar beet recorded data}

Ten plants were chosen at random from the middle ridges at 110 days from sowing to determine the following characteristics:

1. Leaf area index (LAI) was determined according to the method described by Watson (1958).

2. Photosynthetic pigments (chlorophyll $a, b$ and carotenoids "mg/g") were determined in the fresh leaves as mentioned by Wettestien (1957).

At harvest (after 210 days from sowing), ten plants were taken at random from the guarded ridges of each plot to determine the following characteristics:

Morphological root traits:

1. Root length and diameter $(\mathrm{cm})$.

2. Root fresh weight/plant (g).

Quality parameters:

1. Sucrose percentage was determined in fresh macerated root according to the method of Carruthers \& Oldfield (1960). 
2. Impurities (K, $\mathrm{Na}$ and $\alpha$-amino $\mathrm{N}$ concentration) in root were determined as described by Cooke \& Scott (1993).

Sucrose $\%$ and impurities concentration were done on fresh samples of sugar beet roots at Laboratory of El-Nubaria Sugar Factory, El-Beheira Governorate, Egypt.

3. Sugar lost to molasses $\%(\mathrm{SLM} \%)=0.14(\mathrm{Na}$ $+\mathrm{K})+0.25(\alpha$-amino $\mathrm{N})+0.5$ (Deviller, 1988).

4. Extracted sugar\% $(\mathrm{ES} \%)=$ Sucrose $\%$ SLM $\%-0.6$

(Dexter et al., 1967).

5. Quality index (QI) = (extracted sugar\%/ sucrose \%) x $100 \quad$ (Cooke \& Scott, 1993).

\section{Yield and yield contributing traits:}

1. Top and root yields/fed were determined on plot weight $(\mathrm{kg})$ and converted to tons/fed.

2. Sugar yield/fed (ton) was calculated according to the following equation :

Sugar yield/fed (ton)= Extracted sugar \% x root yield/fed (ton).

\section{Statistical analysis}

The collected data were statistically analyzed as shown by Snedecor \& Cochran (1981). Least significant difference (LSD) method was used to compare the differences between treatment means at $5 \%$ level of probability as mentioned by Waller \& Duncan (1969). Data presented in Tables 2 and 3 were expressed as mean $\pm \mathrm{SE}$ and the statically analysis was performed using one-way analysis of variance according to Steel \& Torrie (1980).

\section{Results and Discussion}

Effects of photo-chemical and biological treatments on raw vinasse and the influence of the three forms of vinasse on sandy soil

Data in Table 3 showed that the lowest values of EC, HMF, K, P, TN and COD contents were detected in the biologically treated vinasse, as well as $\mathrm{pH}$ and phenolic compounds in photochemically treated. These findings may be attributed to the positive effect of these treatments, which allow an increasing degradation of organic compounds, COD, BOD, organic carbon and complete the removal of HMF and phenolic compounds from cane vinasse. These findings are in line with those found by Parnaudeau et al. (2008), who clarified that increasing the ratio of the total content of phenols in vinasse could be linked to increased vinasse concentration, which led to an improvement in the abundance of phenolic compounds in comparison with raw vinasse. Thus, data in Table 3 demonstrated that biological treatment and photo-chemical oxidation of cane vinasse can completely remove or particularly degraded the undesirable compounds by un-harmful way. Moreover, Pleurotus ostreatus fungus showed a strong potential for HMF and COD removal, as well as particular degradation of phenolic compounds. Numerous modifications in physicochemical properties resulted from the use of different vinasse treatments. In this respect, Ferreira et al. (2011) reported that vinasse with slightly acidic $\mathrm{pH}$ adjusted to 6.0 favours the growth of $P$. ostreatus on raw vinasse.

TABLE 3. Some physical and chemical characteristics of photo-chemically $\left(V_{2}\right)$ and biologically $\left(V_{3}\right)$ treated cane vinasse, as compared to raw vinasse $\left(\mathrm{V}_{1}\right)$

\begin{tabular}{|c|c|c|c|c|c|c|c|c|c|c|c|}
\hline \multirow{2}{*}{$\begin{array}{l}\text { Vinasse } \\
\text { treatments }\end{array}$} & \multirow{2}{*}{$\begin{array}{c}\text { Moisture } \\
\%\end{array}$} & \multirow{2}{*}{ Density } & \multirow{2}{*}{$\begin{array}{l}\text { Color } \\
\text { conc. }\end{array}$} & \multirow{2}{*}{ pH } & \multirow{2}{*}{$E C(d S / m)$} & \multirow{2}{*}{$\begin{array}{c}\text { HMF } \\
(\mathrm{mL} / \mathbf{1 0 0 m L})\end{array}$} & \multirow{2}{*}{$\begin{array}{l}\text { Total } \\
\text { phenols } \\
\text { (ppm) }\end{array}$} & \multirow[t]{2}{*}{$\mathbf{K}$} & \multirow{2}{*}{$\begin{array}{l}\mathrm{P} \\
\%\end{array}$} & \multirow{2}{*}{\multicolumn{2}{|c|}{$\begin{array}{c}\text { TN COD BOD } \\
\mathrm{mg} \mathrm{O}_{2} / \mathrm{L}\end{array}$}} \\
\hline & & & & & & & & & & & \\
\hline Raw vinasse & $\begin{array}{c}60.3 \pm \\
0.29\end{array}$ & 1.035 & 41000 & $\begin{array}{l}4.5 \pm \\
0.00\end{array}$ & $\begin{array}{l}12 \pm \\
0.40\end{array}$ & $\begin{array}{c}54 \pm \\
3.1\end{array}$ & $\begin{array}{l}0.41 \pm \\
0.005\end{array}$ & 5.44 & 0.65 & 3.05 & 4850022500 \\
\hline $\begin{array}{l}\text { Photo- } \\
\text { chemically }\end{array}$ & $\begin{array}{c}65.5 \pm \\
0.55\end{array}$ & 1.035 & 2409 & $\begin{array}{l}4.3 \pm \\
0.05\end{array}$ & $\begin{array}{l}7.3 \pm \\
0.40\end{array}$ & $\begin{array}{c}7.5 \pm \\
1.5\end{array}$ & $\begin{array}{l}0.13 \pm \\
0.004\end{array}$ & 5.44 & 0.65 & 3.05 & 3100024000 \\
\hline Biologically & $\begin{array}{c}69.4 \pm \\
0.15\end{array}$ & 1.013 & 1632 & $\begin{array}{l}5.1 \pm \\
0.20\end{array}$ & $\begin{array}{l}5.0 \pm \\
0.10\end{array}$ & Nil & $\begin{array}{c}0.34 \pm \\
0.02\end{array}$ & 4.81 & 0.57 & 2.44 & 2960018900 \\
\hline
\end{tabular}

HMF: Hydroxyl methyl furfural, TN: Total nitrogen, COD: Chemical oxygen demand and BOD: Biological oxygen demand. 
Furthermore, Plácido \& Capareda (2015) mentioned that, although biological treatment by $P$. ostreatus is suitable for $\mathrm{HMF}$ and COD removal, the bio-degradable enzymes produced by the fungus (ligninolytic, laccase and peroxidase manganese) are directly related to molecule breaking, which due to non-specific system of high redox potential. Moreover, Vilara et al. (2018) mentioned that mostly ligninolytic enzymes action is considered the main responsible for physical-chemical parameters (phenols, COD and BOD). The effects of the photo-chemically and biologically treatments on vinasse color are shown in Fig. 1.

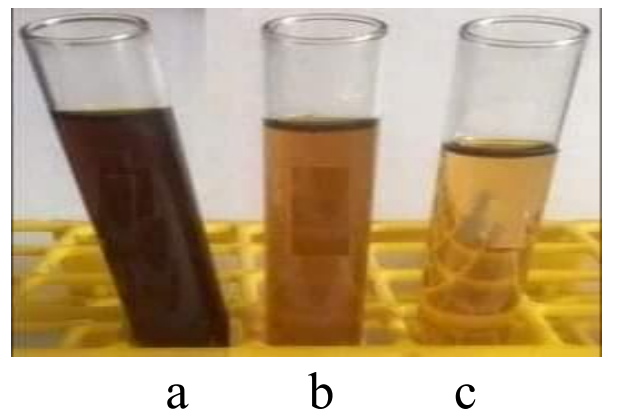

Fig. 1. Effect of the photo-chemically and biologically treatments on vinasse color concentration [a: Untreated (control), b: Photo-chemically treated and c: Biologically treated].

Data in Table 4 showed that the sandy soil characteristics were significantly affected by applying the three different forms of vinasse either individually or in combination with different rates of potassium sulphate, during the two growing seasons, as compared to that given $100 \%$ potassium sulphate alone. The results cleared that the addition of vinasse and potassium sulphate led to a slight decrease in $\mathrm{pH}$, which may be due to the acidic nature of vinasse, as well as a slight increase in salinity (EC) of sandy soil (Table, 4), as compared to the soil $\mathrm{pH}$ and $\mathrm{EC}$ before their application (Table, 1). These observations are in line with those obtained by Abd-El-Kaway (2006). These results may be attributed to that the increase of the vinasse rate, led to a slight increase in the insoluble acid fraction, because vinasse is an acidic liquid with $\mathrm{pH}$ between 4 and 5 (Arafat \& Yassen, 2002; Christofoletti et al., 2013). Meanwhile, adding $100 \%$ of the recommended rate of K-fertilizer as potassium sulphate and/or 100\% raw vinasse gave the highest values of total nitrogen \% (TN\%). A reduction in the concentration of $\mathrm{TN} \%$ was found, when the soil was fertilized with biologically treated vinasse. This result could be attributed to fungus nutritional requirement for biomass (Vilara et al., 2018). On the other hand, K, P elements and OC $\%$, as well as soil microbial activity were increased. These results are in line with those mentioned by Vadivel et al. (2014) and Osman et al. (2016).

Data in the same table also cleared that supplying the soil with the raw vinasse individually or combined with variable portions of K-fertilizer as $\mathrm{K}_{2} \mathrm{SO}_{4}$ resulted in lower values of DHA compared with those recorded by the single or combined applications of photo-chemically and/or biologically treated vinasse, as well as $\mathrm{K}_{2} \mathrm{SO}_{4}$ alone in both seasons.

It worthily to mention the high values of DHA were obtained with treated soil by the combinations of $75 \% \mathrm{~K}_{2} \mathrm{O}+25 \%$ vinasse and $50 \% \mathrm{~K}_{2} \mathrm{O}+50 \%$ vinasse/fed under the various vinasse treated in both season. These findings are consistent with what was stated by (Yuan \& Yue, 2012), which reported that dehydrogenases are one of the most important indicators used to assess soil microbial activity since they occur intracellular in all living microbial cells. In this respect, Subhani et al. (2011) reported that DHA is a beneficial predictor of microbiological redox systems and could be considered a fair and sufficient measure of microbial oxidative activity in the soil. However, fertilization of major elements, i.e. NPK could affect the population of soil microorganisms and consequently, soil enzymatic activities (Barabasz et al., 2002). The maximum values of $\mathrm{P} \%, \mathrm{~K} \%$ and activity of dehydrogenase enzyme were attained with applying $50 \% \mathrm{~K}_{2} \mathrm{O}+50 \%$ biologically treated vinasse/fed to the soil.

Effects of potassium sulphate, the three forms of vinasse and their combinations on the studied traits of sugar beet grown in a sandy soil

Data in Table 5 showed that the application of potassium sulphate, the three forms of vinasse and their combinations had a significant effect on chlorophyll " $a$ " and carotenoids content of sugar beet leaves in both seasons, chlorophyll " $b$ " in the $1^{\text {st }}$ one and LAI in the $2^{\text {nd }}$ one. The highest content of chlorophyll "a" was obtained with fertilizing beet plants with the combination of $(25 \%$ of the recommended rate of $\mathrm{K}$-fertilizer as $\mathrm{K}_{2} \mathrm{SO}_{4}+75 \%$ $\mathrm{V}_{3}$ )/fed in both seasons. The differences among $100 \% \mathrm{~K} /$ fed and the different treatments under vinasse biologically treated, were insignificant in the values of chlorophyll " $a$ ", in the $2^{\text {nd }}$ season. 
TABLE 4. Sandy soil characteristics as affected by potassium sulphate, vinasse forms and their combinations after 40 days from the last application in 2017/2018 and 2018/2019 seasons

\begin{tabular}{|c|c|c|c|c|c|c|c|c|c|c|c|c|c|c|}
\hline \multirow[b]{2}{*}{ Treatments } & \multicolumn{7}{|c|}{$2017 / 2018$} & \multicolumn{7}{|c|}{$2018 / 2019$} \\
\hline & pH & $\begin{array}{c}\text { EC } \\
\text { dS } / \mathbf{m}\end{array}$ & $\begin{array}{l}\mathbf{P} \\
\%\end{array}$ & $\begin{array}{l}\text { TN } \\
\%\end{array}$ & K \% & $\begin{array}{c}\text { OC } \\
\%\end{array}$ & DHA & pH & $\begin{array}{c}\text { EC } \\
d S / m\end{array}$ & $\begin{array}{l}\mathbf{P} \\
\%\end{array}$ & $\begin{array}{l}\text { TN } \\
\%\end{array}$ & K\% & $\begin{array}{c}\text { OC } \\
\%\end{array}$ & DHA \\
\hline $100 \% \mathrm{~K}$ & 7.5 & 1.00 & 0.005 & 0.90 & 0.06 & 0.70 & 36.5 & 7.8 & 0.95 & 0.005 & 0.90 & 0.05 & 0.70 & 36.5 \\
\hline $100 \% \mathrm{~V}_{1}$ & 7.5 & 1.00 & 0.005 & 0.90 & 0.07 & 1.00 & 24.2 & 7.8 & 1.00 & 0.005 & 0.90 & 0.06 & 1.55 & 14.2 \\
\hline $75 \% \mathrm{~K}+25 \% \mathrm{~V}_{1}$ & 7.5 & 0.90 & 0.003 & 0.80 & 0.06 & 0.77 & 33.8 & 7.8 & 0.81 & 0.001 & 0.70 & 0.04 & 0.80 & 32.8 \\
\hline $50 \% \mathrm{~K}+50 \% \mathrm{~V}_{1}$ & 7.6 & 1.10 & 0.004 & 0.75 & 0.08 & 0.80 & 40.0 & 7.7 & 1.02 & 0.002 & 0.70 & 0.07 & 0.90 & 39.9 \\
\hline $25 \% \mathrm{~K}+75 \% \mathrm{~V}_{1}$ & 7.5 & 1.05 & 0.005 & 0.65 & 0.05 & 1.00 & 34.5 & 7.5 & 0.94 & 0.004 & 0.60 & 0.04 & 1.17 & 31.9 \\
\hline $100 \% \mathrm{~V}_{2}$ & 7.5 & 1.05 & 0.004 & 0.85 & 0.08 & 1.50 & 35.0 & 7.5 & 1.20 & 0.003 & 0.80 & 0.07 & 1.95 & 32.8 \\
\hline $75 \% \mathrm{~K}+25 \% \mathrm{~V}_{2}$ & 7.7 & 1.10 & 0.005 & 0.80 & 0.05 & 0.74 & 42.0 & 7.8 & 1.10 & 0.004 & 0.80 & 0.04 & 0.80 & 44.7 \\
\hline $50 \% \mathrm{~K}+50 \% \mathrm{~V}_{2}$ & 7.5 & 1.20 & 0.003 & 0.40 & 0.05 & 0.84 & 40.0 & 7.6 & 1.30 & 0.002 & 0.10 & 0.04 & 0.94 & 40.0 \\
\hline $25 \% \mathrm{~K}+75 \% \mathrm{~V}_{2}$ & 7.6 & 1.30 & 0.018 & 0.09 & 0.20 & 1.10 & 35.0 & 7.5 & 1.03 & 0.035 & 0.04 & 0.30 & 1.16 & 32.9 \\
\hline $100 \% \mathrm{~V}_{3}$ & 7.5 & 1.20 & 0.028 & 0.07 & 0.20 & 1.36 & 39.3 & 7.5 & 1.00 & 0.039 & 0.04 & 0.26 & 1.86 & 40.0 \\
\hline $75 \% \mathrm{~K}+25 \% \mathrm{~V}_{3}$ & 7.8 & 0.90 & 0.024 & 0.04 & 0.15 & 1.50 & 42.0 & 7.8 & 1.03 & 0.038 & 0.03 & 0.19 & 2.36 & 46.0 \\
\hline $50 \% \mathrm{~K}+50 \% \mathrm{~V}_{3}$ & 7.2 & 1.10 & 0.028 & 0.02 & 0.24 & 1.42 & 45.0 & 7.5 & 1.20 & 0.039 & 0.02 & 0.46 & 2.42 & 50.0 \\
\hline $25 \% \mathrm{~K}+75 \% \mathrm{~V}_{3}$ & 7.4 & 1.30 & 0.023 & 0.04 & 0.20 & 1.60 & 40.0 & 7.4 & 0.88 & 0.038 & 0.03 & 0.40 & 2.99 & 42.0 \\
\hline LSD at 0.05 & 0.2 & 0.19 & 0.002 & 0.04 & 0.01 & 0.14 & 2.3 & 0.1 & 0.05 & 0.002 & 0.05 & 0.16 & 0.17 & 7.5 \\
\hline
\end{tabular}

$100 \% \mathrm{~K}: 48 \mathrm{~kg} \mathrm{~K} \mathrm{O} /$ fed as potassium sulphate, $100 \% \mathrm{~V}_{1}: 707.6 \mathrm{~L}$ raw vinasse/fed, $100 \% \mathrm{~V}_{2}: 707.6 \mathrm{~L}$ photo-chemically treated vinasse/ fed, $100 \% \mathrm{~V}_{3}: 817.7 \mathrm{~L}$ biologically treated vinasse/fed, EC: electrical conductivity, P\%: Phosphorus\%, TN: Total nitrogen, OC: Organic carbon, and DHA: Dehydrogenase activity ( $\mu \mathrm{g}$ of triphenyl formazan/g dry soil/day).

TABLE 5. Photosynthetic pigments (mg/g leaf fresh weight) and leaf area index (LAI) of sugar beet as affected by potassium sulphate, vinasse forms and their combinations in 2017/2018 and 2018/2019 seasons

\begin{tabular}{|c|c|c|c|c|c|c|c|c|}
\hline \multirow{3}{*}{ Treatments } & \multicolumn{4}{|c|}{$2017 / 2018$} & \multicolumn{4}{|c|}{ 2018/2019 } \\
\hline & Chl. " $a$ " & Chl. "b" & Carot. & \multirow{2}{*}{ LAI } & Chl. " $a$ " & Chl. " $b$ " & Carot. & \multirow{2}{*}{ LAI } \\
\hline & \multicolumn{3}{|c|}{ (mg/g f.w) } & & \multicolumn{3}{|c|}{ (mg/g f.w) } & \\
\hline $100 \% \mathrm{~K}$ & 4.16 & 2.31 & 1.31 & 3.65 & 4.61 & 2.76 & 1.06 & 3.74 \\
\hline $100 \% \mathrm{~V}_{1}$ & 3.96 & 2.29 & 0.83 & 3.76 & 3.41 & 2.52 & 0.69 & 3.43 \\
\hline $75 \% \mathrm{~K}+25 \% \mathrm{~V}_{1}$ & 4.41 & 2.51 & 1.10 & 3.07 & 4.78 & 1.80 & 1.04 & 3.23 \\
\hline $50 \% \mathrm{~K}+50 \% \mathrm{~V}_{1}$ & 4.34 & 2.34 & 1.07 & 3.18 & 3.96 & 1.73 & 0.96 & 3.28 \\
\hline $25 \% \mathrm{~K}+75 \% \mathrm{~V}_{1}$ & 4.36 & 2.38 & 0.88 & 3.49 & 4.58 & 1.62 & 0.84 & 3.29 \\
\hline $100 \% \mathrm{~V}_{2}$ & 4.75 & 2.92 & 1.49 & 3.85 & 4.96 & 2.44 & 1.35 & 3.72 \\
\hline $75 \% \mathrm{~K}+25 \% \mathrm{~V}_{2}$ & 4.37 & 2.31 & 0.89 & 3.46 & 3.49 & 2.35 & 1.05 & 3.45 \\
\hline $50 \% \mathrm{~K}+50 \% \mathrm{~V}_{2}$ & 4.35 & 2.59 & 1.12 & 3.81 & 4.23 & 2.34 & 1.16 & 3.43 \\
\hline $25 \% \mathrm{~K}+75 \% \mathrm{~V}_{2}$ & 4.70 & 2.81 & 1.50 & 3.87 & 4.53 & 3.83 & 1.39 & 3.63 \\
\hline $100 \% \mathrm{~V}_{3}$ & 5.76 & 3.95 & 1.84 & 4.20 & 5.11 & 2.36 & 1.43 & 4.02 \\
\hline $75 \% \mathrm{~K}+25 \% \mathrm{~V}_{3}$ & 4.61 & 2.47 & 1.36 & 3.76 & 4.14 & 2.04 & 1.17 & 3.57 \\
\hline $50 \% \mathrm{~K}+50 \% \mathrm{~V}_{3}$ & 5.36 & 2.86 & 1.44 & 3.86 & 4.52 & 2.21 & 1.18 & 3.71 \\
\hline $25 \% \mathrm{~K}+75 \% \mathrm{~V}_{3}$ & 5.81 & 3.51 & 1.48 & 4.08 & 5.44 & 2.10 & 1.40 & 3.85 \\
\hline LSD at 0.05 & 0.45 & 0.85 & 0.67 & NS & 1.11 & NS & 0.44 & 0.19 \\
\hline
\end{tabular}

NS: Insignificant difference, $100 \% \mathrm{~K}: 48 \mathrm{~kg} \mathrm{~K} \mathrm{O} /$ fed as potassium sulphate, $100 \% \mathrm{~V}_{1}: 707.6 \mathrm{~L}$ raw vinasse/fed, $100 \% \mathrm{~V}_{2}: 707.6 \mathrm{~L}$ photochemically treated vinasse/fed, $100 \% \mathrm{~V}_{3}: 817.7 \mathrm{~L}$ biologically treated vinasse/fed, Chl: Chlorophyll, Carot.: Carotenoids and LAI: Leaf area index. 
Fertilizing beets with the different forms of biologically treated vinasse and/or a combination of $\left(25 \% \mathrm{~K}+75 \% \mathrm{~V}_{3}\right) /$ fed resulted in marked increases in chlorophyll " $a$ " and "b ", in the $1^{\text {st }}$ season, as compared to that fertilized with $100 \%$ $\mathrm{K} /$ fed. The positive effect of biologically treated vinasse may be due to its beneficial contents of some chelate organic micro and macro nutrients and increasing the bio-availability of NPK, which is an important function in the formation of photosynthetic pigments as mentioned by Parnaudeau et al. (2006).

Data also cleared that sugar beet fertilized with the different forms of photo-chemically and/or biologically treated vinasse, resulted in differences among the values of carotenoids that were not great enough to reach of the level of significance, in comparison to the check treatment, i.e. $100 \% \mathrm{~K} / \mathrm{fed}$, in both seasons.

In the same table, data cleared that supplying sugar beet with $100 \% \mathrm{~V}_{3}$ /fed caused the highest significant increase in the values of LAI, as compared to that given $100 \% \mathrm{~K} /$ fed as $\mathrm{K}_{2} \mathrm{SO}_{4}$, in the $2^{\text {nd }}$ season. This finding can be attributed to the positive impact of increasing chlorophyll " $a$ ", which allowed an efficient use of photosynthesis for the storage of net assimilation rate synthesis output and thus accelerated vegetative growth and increased LAI as explained by Christofoletti et al. (2013).

Data in the Table 6 showed that soil application of potassium sulphate, differently treated forms of vinasse and its combinations had a significant effects in root diameter and its fresh weight per plant in both growing seasons, as well as root length in the $2^{\text {nd }}$ one. Soil application with $\left(75 \% \mathrm{~K}+25 \% \mathrm{~V}_{3}\right) /$ fed led to marked increment in root diameter (in both seasons) and root fresh weight/plant (in the $2^{\text {nd }}$ one), as compared to the individual fertilization with $100 \% \mathrm{~K}\left(48 \mathrm{~kg} \mathrm{~K}_{2} \mathrm{O} /\right.$ fed as $\left.\mathrm{K}_{2} \mathrm{SO}_{4}\right)$. Substantial increments in root length were obtained with $\left(75 \% \mathrm{~K}+25 \% \mathrm{~V}_{2}\right.$ and/ or $\mathrm{V}_{3}$ ) in the $2^{\text {nd }}$ season, as compared to $100 \% \mathrm{~K}$ fertilization. The longest and heaviest roots were attained in both seasons, as well as the thickest roots in the $2^{\text {nd }}$ season, when sugar beet was fertilized with $75 \% \mathrm{~K}+25 \% \mathrm{~V}_{3} /$ fed.

TABLE 6. Root length $(\mathrm{cm})$, diameter $(\mathrm{cm})$ and its fresh weight/plant $(\mathrm{g})$ of sugar beet as affected by potassium sulphate, vinasse forms and their combinations in 2017/2018 and 2018/2019 seasons

\begin{tabular}{|c|c|c|c|c|c|c|}
\hline \multirow[b]{2}{*}{ Treatments } & \multicolumn{3}{|c|}{$2017 / 2018$} & \multicolumn{3}{|c|}{$2018 / 2019$} \\
\hline & $\begin{array}{l}\text { Root } \\
\text { length } \\
(\mathrm{cm})\end{array}$ & $\begin{array}{c}\text { Root } \\
\text { diameter } \\
(\mathrm{cm})\end{array}$ & $\begin{array}{c}\text { Root fresh } \\
\text { weight/plant } \\
\text { (g) }\end{array}$ & $\begin{array}{c}\text { Root } \\
\text { length } \\
(\mathrm{cm})\end{array}$ & $\begin{array}{c}\text { Root } \\
\text { diameter } \\
(\mathrm{cm})\end{array}$ & $\begin{array}{c}\text { Root fresh } \\
\text { weight/plant } \\
\text { (g) }\end{array}$ \\
\hline $100 \% \mathrm{~K}$ & 31.13 & 13.17 & 1113 & 30.30 & 12.60 & 1021 \\
\hline $100 \% \mathrm{~V}_{1}$ & 29.80 & 10.60 & 817 & 29.07 & 12.47 & 903 \\
\hline $75 \% \mathrm{~K}+25 \% \mathrm{~V}_{1}$ & 30.47 & 11.13 & 893 & 30.73 & 12.87 & 934 \\
\hline $50 \% \mathrm{~K}+50 \% \mathrm{~V}_{1}$ & 30.47 & 10.73 & 859 & 30.40 & 12.67 & 929 \\
\hline $25 \% \mathrm{~K}+75 \% \mathrm{~V}_{1}$ & 29.87 & 10.73 & 743 & 29.60 & 12.60 & 910 \\
\hline $100 \% \mathrm{~V}_{2}$ & 30.27 & 11.40 & 855 & 29.93 & 12.40 & 939 \\
\hline $75 \% \mathrm{~K}+25 \% \mathrm{~V}_{2}$ & 31.53 & 13.53 & 1055 & 31.77 & 13.40 & 1037 \\
\hline $50 \% \mathrm{~K}+50 \% \mathrm{~V}_{2}$ & 31.13 & 13.20 & 919 & 30.93 & 12.93 & 1018 \\
\hline $25 \% \mathrm{~K}+75 \% \mathrm{~V}_{2}$ & 30.93 & 11.73 & 909 & 30.60 & 12.73 & 953 \\
\hline $100 \% \mathrm{~V}_{3}$ & 30.87 & 11.80 & 1016 & 31.20 & 13.53 & 969 \\
\hline $75 \% \mathrm{~K}+25 \% \mathrm{~V}_{3}$ & 31.87 & 14.33 & 1146 & 32.87 & 14.27 & 1125 \\
\hline $50 \% \mathrm{~K}+50 \% \mathrm{~V}_{3}$ & 31.13 & 13.93 & 1129 & 32.33 & 13.93 & 1072 \\
\hline $25 \% \mathrm{~K}+75 \% \mathrm{~V}_{3}$ & 30.73 & 13.20 & 1064 & 31.27 & 13.87 & 995 \\
\hline LSD at 0.05 & NS & 0.82 & 243 & 1.09 & 1.18 & 80 \\
\hline
\end{tabular}

NS: Insignificant difference, $100 \% \mathrm{~K}: 48 \mathrm{~kg} \mathrm{~K}_{2} \mathrm{O} /$ fed as potassium sulphate, $100 \% \mathrm{~V}_{1}: 707.6 \mathrm{~L}$ raw vinasse/fed, $100 \% \mathrm{~V}_{2}: 707.6 \mathrm{~L}$ photochemically treated vinasse/fed, $100 \% \mathrm{~V}_{3}: 817.7 \mathrm{~L}$ biologically treated vinasse/fed. 
Insignificant variances were found in the previously-mentioned traits as affected by applying the combinations of $(75 \% \mathrm{~K}+25 \%$ vinasse) and $(50 \% \mathrm{~K}+50 \%$ vinasse $) /$ fed under the various forms of vinasse in both seasons. Supplying beets with $75 \% \mathrm{~K}+25 \% \mathrm{~V}_{3} /$ fed led to substantial increases amounted to 1.16 and $1.67 \mathrm{~cm}$ in root diameter in the $1^{\text {st }}$ and $2^{\text {nd }}$ season, respectively, corresponding to $104 \mathrm{~g}$ in root fresh weight/plant in the $2^{\text {nd }}$ one, as compared to that fertilization with $100 \% \mathrm{~K} / \mathrm{fed}$. These findings may be referred to the biological role done by Pleurotus fungus $\left(\mathrm{V}_{3}\right)$ in the reduction of $\mathrm{EC}$, HMF and COD contents in raw vinasse $\left(\mathrm{V}_{1}\right)$.

Moreover, despite the high value of phenols in the biologically treated vinasse than the chemical treatment as shown in Table 3, it may had been broken down into short chains that plants can handle physiologically (Vilara et al., 2018). The fertilization with the biologically treated vinasse at $100 \%$ level showed the superiority as the same level of photo-chemically treated vinasse for each characteristic in this respect, while the raw vinasse treatment came in the last rank in both seasons. These observations coincide with those found by Parnaudeau et al. (2006). Moreover, Retes-Pruneda et al. (2014) explained that treating vinasse with Pleurotus fungus reduced the toxicity and improving its physical and chemical properties.

Results in Table 7 indicated that soil application of potassium sulphate and its combinations with the different treated vinasse appreciably affected sucrose $\%$, potassium content in sugar beet root, sugar lost to molasses\% (SLM\%), extracted sugar\% and quality index, in both seasons, as well as, sodium and $\alpha$-amino $\mathrm{N}$ contents, in the $2^{\text {nd }}$ one.

Lower contents of juice impurities and SLM\% were detected, when sugar beet was fertilized with the different treatments associated with biologically treated vinasse than the other treatments correlated with raw and/or photochemically vinasse, in both seasons. These results may be ascribed to comparatively better conditions in the rhizospheric zone as a result of the role of Pleurotus fungus in increasing degradation of organic compounds such as COD and total organic carbon and complete removal of HMF content and melanoidins from biodegraded vinasse, producing a non-toxic effluent and lowering organic contents as $\mathrm{K}$ and total N\% as a mentioned by Vilara et al. (2018), which guaranteed more sugar accumulation, good quality and lower impurity contents.

Fertilizing sugar beet with $100 \% \quad \mathrm{~V}_{3} /$ fed increased sucrose $\%$ significantly by 2.40 and 1.91, extracted sugar\% by 2.54 and 2.12 and quality index by 1.96 and 2.33 , in the $1^{\text {st }}$ and $2^{\text {nd }}$ season, respectively, as compared to plants given $100 \% \mathrm{~K} /$ fed $\left(48 \mathrm{~kg} \mathrm{~K}_{2} \mathrm{O}\right.$ as $\left.\mathrm{K}_{2} \mathrm{SO}_{4}\right)$. The difference between $100 \% \mathrm{~V}_{2}$ and $25 \% \mathrm{~K}+75 \% \mathrm{~V}_{2} / \mathrm{fed}$, in their effect on the previously-mentioned traits was insignificant, in both seasons. However, significant variances in sucrose and extracted sugar percentages were found between $100 \% \mathrm{~V}_{3}$ and $25 \% \mathrm{~K}+75 \% \mathrm{~V}_{3} / \mathrm{fed}$, in the $1^{\text {st }}$ season.

As compared to beets fertilized with $100 \%$ $\mathrm{K} / \mathrm{fed}$, statistical increases in sucrose \% (in both seasons) and extracted sugar\% (in the $1^{\text {st }}$ one) were obtained with the different treatments associated with biologically treated vinasse. Meanwhile, insignificant difference in the quality index was found when beets were fertilized with $75 \% \mathrm{~K}+25 \% \mathrm{~V}_{3} /$ fed, as well as $50 \% \mathrm{~K}+50 \%$ $\mathrm{V}_{3} /$ fed. These findings were true in both seasons. These results are in line with those obtained by Osman et al. (2016), who confirmed that vinasse is a vital source of potassium. They added that its utilization could decrease the requirement for inorganic potassium fertilizers on many crops. Besides, these results may be due to beneficial role of supplying plants with vinasse, which contains chelate organic material such as boron and organic potassium as a mentioned by Rodríguez (2000).

Data in Table 8 proved that adding potassium sulphate, differently treated vinasse and its combinations to the sandy soil appreciably affected root and sugar yields/fed, in the two growing seasons, as well as top yield/fed in the $2^{\text {nd }}$ one.

Insignificant variances were detected in root yield/fed of sugar beet fed with treatments including the biologically treated vinasse $\left(\mathrm{V}_{3}\right)$, as compared to that fertilized with $100 \% \mathrm{~K}$, in both seasons.

Data analysis showed insignificant differences among $100 \% \mathrm{~K} /$ fed, combinations of $\left(75 \% \mathrm{~K}+25 \% \mathrm{~V}_{3}\right)$ and $\left(50 \% \mathrm{~K}+50 \% \mathrm{~V}_{3}\right) /$ fed, in their influence on root yield/fed, but all of them surpassed the other fertilization treatments 
including raw vinasse and/or photo-chemically treated vinasse, in both seasons. Application of $\left(50 \% \mathrm{~K}+50 \% \mathrm{~V}_{3}\right)$ increased root yield/fed substantially and overpassed $\left(100 \% \mathrm{~V}_{3}\right)$ and $(25 \%$ $\left.\mathrm{K}+75 \% \mathrm{~V}_{3}\right)$, in both seasons. Adding of $(50 \% \mathrm{~K}$ $+50 \%$ biologically treated vinasse)/fed to the soil had an increase in root yield/fed reached 0.98 and 0.71 ton, in the $1^{\text {st }}$ and $2^{\text {nd }}$ season, respectively, as compared to that given with $100 \% \mathrm{~K} /$ fed.

The results in the same table cleared that there were substantial increases in sugar yield/ fed, when beets were fertilized with the different potassium rates related to biologically treated vinasse, as compared to those fertilized with the same rates of potassium including photochemically treated and/or raw vinasse, in both seasons.

Adding biologically treated vinasse $\left(\mathrm{V}_{3}\right)$ at $100 \%$ level, $\left(75 \% \mathrm{~K}+25 \% \mathrm{~V}_{3}\right),(50 \% \mathrm{~K}+$ $\left.50 \% \mathrm{~V}_{3}\right)$ and $\left(25 \% \mathrm{~K}+75 \% \mathrm{~V}_{3}\right) /$ fed resulted in significant increases in sugar yield/fed amounted to $9.93,6.70,10.17$ and $9.93 \%$, in the $1^{\text {st }}$ season, corresponding to $11.96,6.36,8.65$ and 10.43 $\%$, in the $2^{\text {nd }}$ one, successively, as compared to that gained with $100 \% \mathrm{~K}$-fertlizer/fed as $\mathrm{K}_{2} \mathrm{SO}_{4}$. The lowest values in the above-mentioned traits were recorded with raw vinasse treatments, as compared to the other vinasse ones, in both seasons. The positive effect of photo-chemically and biologically treated vinasse on root and sugar yields may be attributed to their stimulatory effect as an optimal un-harmful type of vinasse. These results are in harmony with those obtained by Chen et al. (2012), Nkoa (2014) and Vilara et al. (2018). Moreover, the use of different rates of potassium sulphate alone and/or in combination with vinasse forms as a source of potassium maybe improved chemical properties and soil fertility as explain by Rodríguez (2000), which led to stimulating photosynthesis process, consequently increased root diameter (Table 6), i.e. expansion of cambium rings and increased and hence more storage of sucrose in roots (Table 7 ), which positively reflected on root and sugar yields as shown in Table 8.

TABLE 7. Sucrose\%, impurities profile (meq/100 g beet), sugar lost to molasses\%, extracted sugar \% and quality index of sugar beet as affected by potassium sulphate, vinasse forms and their combinations in 2017/2018 and 2018/2019 seasons

\begin{tabular}{|c|c|c|c|c|c|c|c|c|c|c|c|c|c|c|}
\hline \multirow{3}{*}{ Treatments } & \multicolumn{7}{|c|}{$2017 / 2018$} & \multicolumn{7}{|c|}{ 2018/2019 } \\
\hline & \multirow{2}{*}{$\mathrm{S} \%$} & $\mathbf{K}$ & $\mathbf{N a}$ & $\alpha-\mathbf{a} N$ & \multirow{2}{*}{$\begin{array}{c}\text { SLM } \\
\%\end{array}$} & \multirow{2}{*}{$\begin{array}{l}\text { ES } \\
\%\end{array}$} & \multirow[t]{2}{*}{ QI } & \multirow[t]{2}{*}{$\mathrm{S} \%$} & $\mathbf{K}$ & $\mathrm{Na}$ & $\alpha-\mathbf{a} \mathbf{N}$ & \multirow{2}{*}{$\begin{array}{l}\text { SLM } \\
-\%\end{array}$} & \multirow{2}{*}{$\begin{array}{l}\text { ES } \\
\%\end{array}$} & \multirow[t]{2}{*}{ QI } \\
\hline & & \multicolumn{3}{|c|}{ meq $/ 100 \mathrm{~g}$ beet } & & & & & \multicolumn{3}{|c|}{ meq $/ 100 \mathrm{~g}$ beet } & & & \\
\hline $100 \% \mathrm{~K}$ & 18.33 & 3.46 & 1.36 & 1.06 & 1.44 & 16.29 & 88.87 & 17.02 & 4.07 & 1.11 & 0.96 & 1.47 & 14.95 & 87.84 \\
\hline $100 \% \mathrm{~V}_{1}$ & 18.29 & 3.82 & 1.50 & 0.94 & 1.48 & 16.21 & 88.63 & 17.68 & 4.12 & 1.77 & 1.15 & 1.61 & 15.47 & 87.50 \\
\hline $75 \% \mathrm{~K}+25 \% \mathrm{~V}_{1}$ & 17.48 & 4.93 & 1.57 & 1.29 & 1.73 & 15.15 & 86.67 & 15.40 & 5.30 & 2.25 & 1.51 & 1.93 & 12.87 & 83.57 \\
\hline $50 \% \mathrm{~K}+50 \% \mathrm{~V}_{1}$ & 17.74 & 4.47 & 1.62 & 1.19 & 1.65 & 15.49 & 87.32 & 15.99 & 4.73 & 2.42 & 1.60 & 1.90 & 13.49 & 84.37 \\
\hline $25 \% \mathrm{~K}+75 \% \mathrm{~V}_{1}$ & 17.88 & 4.00 & 1.58 & 1.15 & 1.57 & 15.72 & 87.92 & 17.37 & 4.24 & 1.82 & 1.27 & 1.67 & 15.10 & 86.93 \\
\hline $100 \% \mathrm{~V}_{2}$ & 18.77 & 3.40 & 1.42 & 0.98 & 1.42 & 16.75 & 89.24 & 18.26 & 3.12 & 1.38 & 0.95 & 1.37 & 16.30 & 89.27 \\
\hline $75 \% \mathrm{~K}+25 \% \mathrm{~V}_{2}$ & 18.09 & 4.49 & 1.76 & 1.17 & 1.67 & 15.83 & 87.51 & 17.05 & 4.88 & 1.74 & 1.37 & 1.77 & 14.69 & 86.16 \\
\hline $50 \% \mathrm{~K}+50 \% \mathrm{~V}_{2}$ & 18.43 & 4.31 & 1.71 & 1.12 & 1.62 & 16.20 & 87.90 & 17.08 & 4.41 & 1.82 & 1.34 & 1.71 & 14.77 & 86.48 \\
\hline $25 \% \mathrm{~K}+75 \% \mathrm{~V}_{2}$ & 18.88 & 3.51 & 1.54 & 0.93 & 1.44 & 16.84 & 89.19 & 17.98 & 3.38 & 1.17 & 1.00 & 1.37 & 16.00 & 88.99 \\
\hline $100 \% \mathrm{~V}_{3}$ & 20.73 & 3.01 & 1.21 & 0.86 & 1.31 & 18.83 & 90.83 & 18.93 & 2.73 & 1.12 & 0.88 & 1.26 & 17.07 & 90.17 \\
\hline $75 \% \mathrm{~K}+25 \% \mathrm{~V}_{3}$ & 19.04 & 3.75 & 1.47 & 1.26 & 1.55 & 16.90 & 88.76 & 17.90 & 4.33 & 1.64 & 1.29 & 1.66 & 15.64 & 87.37 \\
\hline $50 \% \mathrm{~K}+50 \% \mathrm{~V}_{3}$ & 19.37 & 3.71 & 1.43 & 0.99 & 1.47 & 17.30 & 89.31 & 18.06 & 4.37 & 1.67 & 1.24 & 1.66 & 15.80 & 87.49 \\
\hline $25 \% \mathrm{~K}+75 \% \mathrm{~V}_{3}$ & 20.31 & 3.09 & 1.47 & 0.83 & 1.34 & 18.37 & 90.45 & 18.79 & 3.14 & 1.11 & 0.96 & 1.34 & 16.85 & 89.68 \\
\hline LSD at 0.05 & 0.38 & 0.67 & NS & NS & 0.15 & 0.42 & 0.84 & 0.78 & 0.76 & 0.48 & 0.23 & 0.14 & 0.76 & 0.93 \\
\hline
\end{tabular}

NS: Insignificant difference, $100 \% \mathrm{~K}: 48 \mathrm{~kg} \mathrm{~K}_{2} \mathrm{O} /$ fed as potassium sulphate, $100 \% \mathrm{~V}_{1}: 707.6 \mathrm{~L} \mathrm{raw}$ vinasse/fed, $100 \% \mathrm{~V}_{2}$ : $707.6 \mathrm{~L}$ photochemically treated vinasse/fed, $100 \% \mathrm{~V}_{3}: 817.7 \mathrm{~L}$ biologically treated vinasse/fed, S\%: Sucrose $\%, \alpha-a$ N: Alpha-amino nitrogen, SLM $\%$ : Ssugar lost to molasses\%, ES\%: Extracted sugar\% and QI: Quality index.

Egypt. J. Agron. 42, No. 3 (2020) 
TABLE 8. Top, root and sugar yields/fed (ton) as affected by potassium sulphate, vinasse forms and their combinations in 2017/2018 and 2018/2019 seasons

\begin{tabular}{lcccccc}
\hline & \multicolumn{3}{c}{$\mathbf{2 0 1 7 / 2 0 1 8}$} & \multicolumn{3}{c}{$\mathbf{2 0 1 8 / 2 0 1 9}$} \\
\cline { 2 - 7 } Treatments & Top yield & Root yield & Sugar yield & Top yield & Root yield & Sugar yield \\
\cline { 2 - 6 } & \multicolumn{3}{c}{ (ton/fed) } & & & (ton/fed) \\
\hline $100 \% \mathrm{~K}$ & 9.33 & 24.69 & 4.03 & 9.10 & 26.27 & 3.93 \\
$100 \% \mathrm{~V}_{1}$ & 8.24 & 22.14 & 3.59 & 8.97 & 24.33 & 3.77 \\
$75 \% \mathrm{~K}+25 \% \mathrm{~V}_{1}$ & 8.72 & 22.69 & 3.44 & 9.27 & 25.13 & 3.23 \\
$50 \% \mathrm{~K}+50 \% \mathrm{~V}_{1}$ & 8.43 & 22.56 & 3.50 & 9.41 & 24.90 & 3.36 \\
$25 \% \mathrm{~K}+75 \% \mathrm{~V}_{1}$ & 8.83 & 21.84 & 3.44 & 9.35 & 24.53 & 3.71 \\
$100 \% \mathrm{~V}_{2}$ & 7.94 & 22.47 & 3.76 & 9.48 & 24.37 & 3.97 \\
$75 \% \mathrm{~K}+25 \% \mathrm{~V}_{2}$ & 9.78 & 23.80 & 3.77 & 9.84 & 25.64 & 3.77 \\
$50 \% \mathrm{~K}+50 \% \mathrm{~V}_{2}$ & 9.45 & 23.27 & 3.77 & 9.79 & 25.76 & 3.80 \\
$25 \% \mathrm{~K}+75 \% \mathrm{~V}_{2}$ & 9.47 & 23.17 & 3.90 & 9.76 & 25.21 & 4.03 \\
$100 \% \mathrm{~V}_{3}$ & 8.23 & 23.50 & 4.43 & 9.89 & 25.75 & 4.40 \\
$75 \% \mathrm{~K}+25 \% \mathrm{~V}_{3}$ & 10.79 & 25.37 & 4.30 & 10.48 & 26.73 & 4.18 \\
$50 \% \mathrm{~K}+50 \% \mathrm{~V}_{3}$ & 9.54 & 25.67 & 4.44 & 10.54 & 26.98 & 4.27 \\
$25 \% \mathrm{~K}+75 \% \mathrm{~V}_{3}$ & 8.90 & 24.11 & 4.43 & 9.85 & 25.74 & 4.34 \\
$\mathrm{LSD}$ at 0.05 & $\mathrm{NS}$ & 1.68 & 0.28 & 0.76 & 1.27 & 0.23 \\
\hline
\end{tabular}

NS: Insignificant difference, $100 \% \mathrm{~K}: 48 \mathrm{~kg} \mathrm{~K}_{2} \mathrm{O} /$ fed as potassium sulphate, $100 \% \mathrm{~V}_{1}: 707.6 \mathrm{~L}$ raw vinasse/fed, $100 \% \mathrm{~V}_{2}: 707.6 \mathrm{~L}$ photochemically treated vinasse/fed, $100 \% \mathrm{~V}_{3}: 817.7 \mathrm{~L}$ biologically treated vinasse/fed.

\section{Conclusion}

Under the conditions of this study, it was found that the addition of $[50 \%$ of the recommended rate of $\mathrm{K}$-fertilizer, i.e. $24 \mathrm{~kg} \mathrm{~K}_{2} \mathrm{O}$ as potassium sulphate $+50 \%$ the biologically treated vinasse (408.85 liters)]/fed can be recommended to get an economical root and sugar yields, which means saving $50 \%$ of required inorganic potassium needed for plant growth. Further research work is suggested to investigate the effect of the long term use of vinasse on soil properties such as soil permeability, salinity, $\mathrm{pH}$ and ground water quality.

\section{$\underline{\text { References }}$}

A.O.A.C. (1980) "Official Methods of Analysis", $13^{\text {th }}$ ed. Association of Official Analytical Chemists. Washington, D.C; USA.

Abd-El-Kaway, A.M. (2006) Utilization of vinasse as a source of potassium for some crops grown in upper Egypt. M.Sc. Thesis. Fac. Agric., Assiut Univ., Egypt.

Afify, A.S., Mahmoud, M.A., Emara, H.A.,
Abdelkreem, K.I. (2009) Phenolic compounds and COD removal from olive mill wastewater by chemical and biological procedures. Australian $J$. Bas. Appl Sci. 3(2), 1087-1095.

APHA (1992) "Standard Methods for the Examination of Water and Wastewater", $18^{\text {th }}$ ed. American Public Health Association, Washington, DC.

Arafat, S., Yassen, A.E. (2002) Agronomic evaluation of fertilizing efficiency of vinasse. $17^{\text {th }}$ World Cong., Soil Sci. Symp.14:1-6.

Barabasz, W., Albińska1, D., Jaśkowska, M., Lipiec, J. (2002) Biological effects of mineral Nitrogen fertilization on soil microorganisms. Pol. J. Environ. Stud. 11(3), 193-198.

Benito, G.G., Miranda, M.P., Rodriguez, De Los Santos D. (1997) Decolorization of wastewater from an alcoholic fermentation process with trametes versicolor. Bioresource Technol. 61, 33-37.

Black, C.A., Evans, D.D., Ensminger, L.E., White, G.L., Clark, F.E. (1981) "Methods of Soil Analysis". Part 2. Pp. 1-100. Agron. Inc. Madison. WI., USA. 
Carruthers, A., Oldfield, J.ET. (1960) Methods for the assessment of beet quality. Int. Sugar J. 63(1), 103105 .

Chen, R.R., Blagodatskaya, E., Senbayram, M., Blagodatsky, S., Myachina, O., Dittert, K., Kuzyakov, Y. (2012) Decomposition of biogas residues in soil and their effects on microbial growth kinetics and enzyme activities. Biomass and Bioenergy, 45, 221-229.

Christofoletti, C.A., Escher, J.P., Correia, J.E., Marinho, J.F.U., Fontanetti, C.S. (2013) Sugarcane vinasse: Environmental implications of its use. Waste Manag. 33, 2752-2761.

Cooke, D.A., Scott, R.K. (1993) "The Sugar Beet Crop", pp. 595-605. Science Practice. Puplished by Chapman and Hall, London.

Decloux, M., Bories, A. (2002) Stillage treatment in the French alcohol fermentation industry. Int. Sugar J. 104, 509-517.

Deviller, P. (1988) Prevision du sucre melasse sucrerie feanases.129:190-200. [C.F. Cooke, D.A. and R.K. Scott (1993), The Sugar Beet Crop Book].

Dexter, S.T., Frankes, M.G., Snyder, F.W. (1967) A rapid and practical method of determining extractable white sugar as may be applied to the evaluation of agronomic practices and grower deliveries in the sugar beet industry. J. Am. Soc. Sugar Beet Technol. 14, 433-454.

España-Gamboa, E., Mijangos-Cortés, J., BarahonaPérez, L., Dominguez-Maldonado, J., HernandezZárate, G., Alzate-Gaviria, L. (2011) Vinasse: Characterization and treatments. Waste Manage. Res. 29, 1235-50.

Ferreira, L.F., Aguiar, M.M., Messias, T.G., Pompeu, G.B. Queijeiro, A.M., Silva, D.P., Monteiro, R.T. (2011) Evaluation of sugar-cane vinasse treated with Pleurotus sajor-caju utilizing aquatic organisms as toxicological indicators. Ecotoxicol. Environ. Saf. 74, 132-7.

Ferweez, H., Abd El-Monem, A.M. (2018) Enhancing yield, quality and profitability of sugar beet combining potassium fertilizer and application date of yeast. Egypt. J. Agron. 40(1), 1-14.

Fitz-Gibbon, F., Singh, D., McMullan, G., Marchant,
R. (1998) The effect of phenolic acids and molasses spent wash concentration on distillery wastewater remediation by fungi. Process. Biochem. 33, 799.

Fuess, L.T., Kiyuna, L.S., Júnior, A.D., Persinoti, G.F., Squina, F.M., Garcia, M.L., Zaiat, M. (2017) Thermophilic two-phase anaerobic digestion using an innovative fixed-bed reactor for enhanced organic matter removal and bio-energy recovery from sugarcane vinasse. Appl. Energy, 189, 480491.

González, L., Mejía, M. (2015) Impact of fertiirrigation with vinasse on ground water quality. Irrig. Drain. 64, 400-7.

Hasanuzzaman, M., Bhuyan, M.H.M.B., Nahar, K., Hossain, Md.S., Al Mahmud, J., Hossen, Md.S., Masud, A.A.C., Moumita, Fujita, M. (2018) Potassium: A vital regulator of plant responses and tolerance to abiotic stresses. Agronomy, 8(3), 31 .

Jackson, M.I. (1973) "Soil Chemical Analysis". Prentice Hall Inc. Englewood cliffs, N.J., USA.

Júnior, A.D.N.F., Koyama, M.H., de Araújo Júnior, M.M., Zaiat, M. (2016) Thermophilic anaerobic digestion of raw sugarcane vinasse. Renew. Energy, 89, 245-252.

Nkoa, R. (2014)Agricultural benefits and environmental risks of soil fertilization with anaerobic digestates: A review. Agronomy for Sustainable Development, 34, 473-492.

Osman. Mona, A., Seddik, Wafaa, M.A., Kenawy, Mona, H.M. (2016) Agronomic evaluation of diluted vinasse as a source of potassium fertilizers for peanut and carrot crops. J. Soil Sci. and Agric. Eng., Mansoura Univ., Egypt, 7(2), 107-116.

Parnaudeau, V., Nicolardot, B., Robert, P., Alavoine, G., Page`s, J., Duchiron, F. (2006) Organic matter characteristics of food processing industry wastewaters affecting their $\mathrm{C}$ and $\mathrm{N}$ mineralization in a soil incubation. Bioresource. Technol. 97, 1284-1295.

Parnaudeau, V., Condom, N., Oliver, R., Cazevieille, P., Recous, S. (2008) Vinasse organic matter quality and mineralization potential,as influenced by raw material, fermentation and concentration processes. Bioresource Technol. 99, 1553-1562.

Egypt. J. Agron. 42, No. 3 (2020) 
Plácido, J., Capareda, S. (2015) Ligninolytic enzymes: A biotechnological alternative for bioethanol production. Bioresources and Bioprocessing, 2, $1-12$.

Reis, C.E.R., Bento, H.B.S., Alves, T.M., Carvalho, A.K.F., De Castro, H.F. (2019) Vinasse treatment within the sugarcane-ethanol industry using ozone combined with anaerobic and aerobic microbial processes. Environ. 6(5), 1-13.

Retes-Pruneda, J.L., Davila-Vazquezb, G., MedinaRamírezc, I., Chavez-Velaa, N.A., LozanoAlvareza, J.A., Alatriste-Mondragond, F., JaureguiRincon, J. (2014) High removal of chemical and biochemical oxygen demand from tequila vinasses by using physicochemical and biological methods. Environ.Technol. 35(14), 1773-1784.

Rocha, M.H., Lora, E.E.S., Venturini, O.J. (2007) Life cycle analysis of diferent alternatives for the treatment and disposal of ethanol vinasse. Proc. Int. Soc. Sugar Cane Technol. 26, 108-114.

Rodríguez, J.G.O. (2000) Effects of vinasse on sugarcane (Saccharum officinarum) productivity. Rev. Fac. Agron. (LUZ). 17, 318-326.

Rodríguez-Félix. E., Contreras-Ramos, Silvia, Davila-Vazquez, M.G., Rodríguez-Campos, J., Marino-Marmolejo, E.N. (2018) Identification and quantification of volatile compounds found in vinasses from two different processes of tequila production. Energies, 11(3), 490.

Snedecor, G.W., Cochran, W.G. (1981) "Statistical Methods", $7^{\text {th }}$ ed. Iowa State Univ. Press, Ames, Iowa, USA.

Steel, R.G.D., Torrie, J.H. (1980) "Principles and Procedures of Statistics, a Biometrical Approach". Mc-Grow-Hill Book Co., $2^{\text {nd }}$ ed., New York, U.S.A.

Subhani, A., Changyong, H., Zhengmiao, Y., Min, L., El-ghamry, A. (2011) Impact of soil environment and agronomic practices on microbial/ dehydrogenase enzyme activity in soil. A Review. Pakistan J. Biologic. Sci. 4, 333-338.

Swain, T., Hillis, W.E. (1959) The Phenolic constitutents of Prunus domestica. The quantitative analysis of constituent's phenolic. J. Sci. Food Agric. 10, 6368.
Tejada, M., Gonzalez, J.L., Garcia-Martinez, A.M., Parrado, J. (2008) Application of green manure and green manure composted with beet vinasse on soil restoration: Effects on soil properties. Bioresources Technol. 99, 4949-4957.

Thalmann, A. (1967) Puber die microbiello aktivita undihr beziekung $\mathrm{zu}$ fruchtbartkeits merkmolen einiger Acherboden besouderer beruckrichtigung der dehydrogenas aktivitat. (TTC. Reduction). Biss. Gieben. Ph.D. Thesis, W. Germany.

Vadivel, R., Paramjit, S.M., Suresh, K.P., Yogeswar, S., Nageshwar, R.D.V.K., Avinash, N. (2014) Significance of vinasses waste management in agriculture and environmental quality- Review. African J. Agric. Res. 9, 2862-2873.

Vilara, D.S., Carvalho, G.O., Pupo, M.M.S., Aguiar, M.M., Torres, N.H., Américo, J.H.P., Cavalcanti, E.B., Eguiluz, K.I.B., Salazar-Banda, G.R., Leite, M.S., Ferreira, L.F.R. (2018) Vinasse degradation using Pleurotus sajor-caju in a combined biological Electrochemical oxidation treatment. Separation and Purification Technol. 192, 287-296.

Waller, R.A., Duncan, D.B. (1969) A bays rule for symmetric multiple comparison problem. Amer. Stat. Assoc. J. 1485-1503.

Walter, A., Dolzan, P., Quilodrán, O., de Oliveira, J.G., da Silva, C., Piacente, F., et al. (2011) Sustainability assessment of bio-ethanol production in Brazil considering land use change, GHG emissions and socio-economic aspects. Energy Policy, 39, 5703 5716.

Watson, D.J. (1958) The dependence of net assimilation rate on leaf area index. Ann. Bot. Lond. N.S., 22, $37-54$.

Wettestien, D.V. (1957) Chlorophyll, lethal und submikroskopische formel wechsel der plastiden Exptl .Cell Res. 12, 427-433.

Yuan, B., Yue, D. (2012) Soil microbial and enzymatic activities across a chronosequence of chinese pine plantation development on the loess plateau of China. Pedosphere, 22, 1-12.

Zappalaa, M., Fallico, B., Arena, E., Verzera, A. (2005) Methods for the determination of HMF in honey: A comparison. Food Control, 16, 273-277. 


\section{استخدام الفيناس كمصدر للتسميد البوتاسى لبنجر السكر ومُحسِّن لتربة رملية}

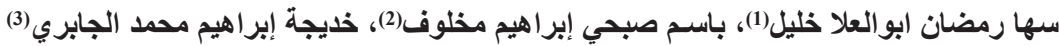

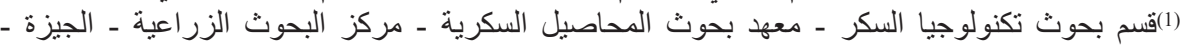

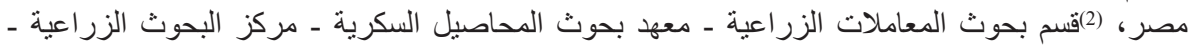

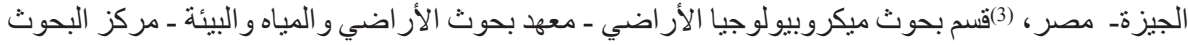

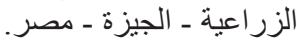

أقيمت تجربتان حقليتان في مزرعة جمعية الحسين - طريق القاهرة_الأسكندرية الصحر اوي - محافظة الجيزة

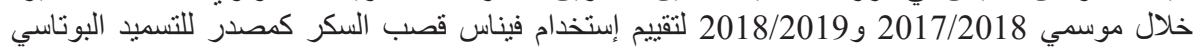

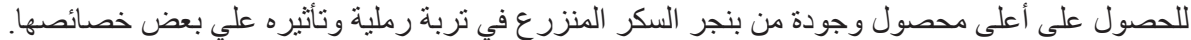
استخدم تصميم القطاعات الكاملة العشو ائية. إنتنملت الدر استة على 13 معاملة هي:

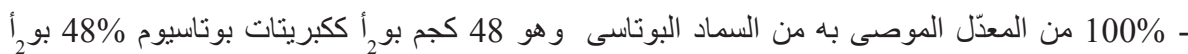

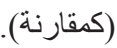

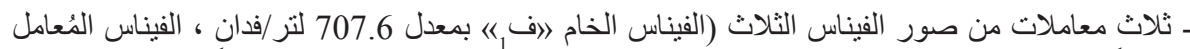

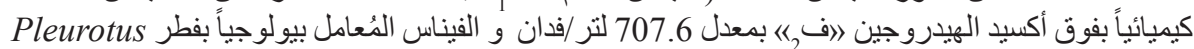

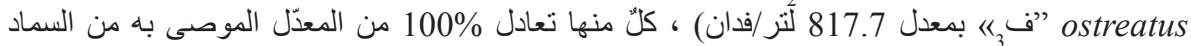

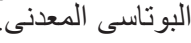

ـ تسع معاملات عبارة عن 75 ، 50 ، 50 و 25 \% من المعدّل الموصى به من السماد البو تاسىى المعدنى منو افقةً مع

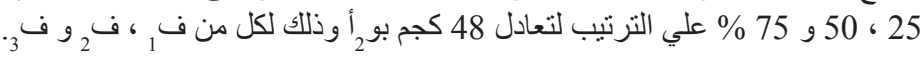

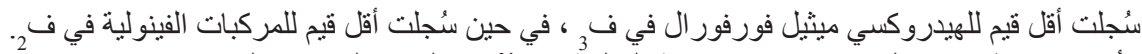

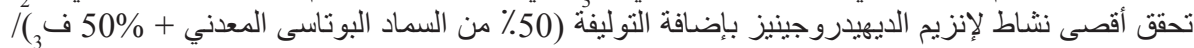

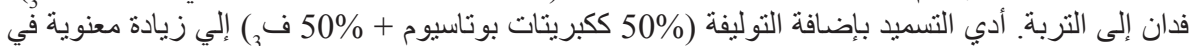

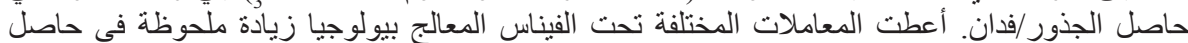

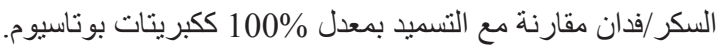

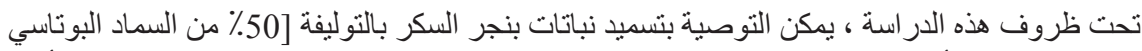

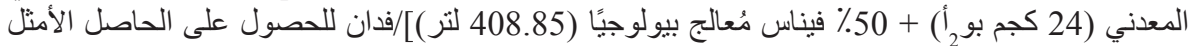

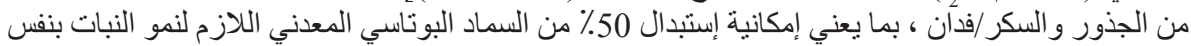
القدر من مصدر عضوى للسماد البوتاسى. 